\title{
A Comparative Study of Canadian Immigration Trends between 2000-2019
}

\author{
Tariq Sardar \\ Research Alumnus, Universidad Azteca Mexico and PRC-Pilot Research Foundation Toronto (ON) Canada
}

\begin{abstract}
Canada is a country in North American continent, known as a "Land of Immigrants" where an averagely 252,962 immigrants since 2000 arrive to live permanently from worldwide every year. Canadian Immigration system is more than 200 years old. The two neighboring countries in South Asian region, India and Pakistan also participate in the immigration program equally however the percentage of migrants is not equal. Some community groups and individuals from Pakistan criticize on Canadian immigration selection policies. The descriptive-comparative research study was designed to understand the gender-wise percentage of worldwide immigration, people from India and Pakistan according to the total population and what contribution the immigrants of both countries make in the growth of overall Canadian population. The study findings are based on previous twenty years' data from 2000 to 2019.
\end{abstract}

Keywords: Immigration, CMAs, Express Entry, Permanent Residence, PNP, Migration, Confederation, Dominion

\section{INTRODUCTION}

$\mathrm{C}$ anada is a country in North America, covering the northern part of the continent and it has the world's largest international border with United States in the Southern Region which is nearly 8,891 kilometers long. The country is divided into 13 sub-national divisions with ten (10) independent provinces and three (3) territories. Canada occupies an area of 9,984,670 kilometers and is the second largest country in the world after Russia. The country is known as a land of immigrants, also a strong and free country which is committed to peace, order and good governance (National Online, 1998: Britannica, 2020: CIC, 2012). Canada was created under the British North America Act on $1^{\text {st }}$ July 1876 and, Ontario, Quebec, New Brunswick and Nova Scotia joined it as the provinces in the beginning. Three years later in 1870, Manitoba and Northwest Territories and next year in 1971, British Columbia joined the Dominion. Prince Edward Island in 1873, Yukon Territory in 1898, Alberta and Saskatchewan in 1905, Newfoundland and Labrador in 1949, and Nunavut Territory in 1999 entered into the confederation of Canada (CIC, 2012: Munroe, 2019).

Every year Canada invites thousands of immigrants from around the world under various categories including Economic and Business (Express Entry, PNP, Investor, Entrepreneur and Self-employed, Agri-food pilot, Atlantic, Quebec, Rural and Northern Programs), Family Sponsorship (Spousal, Children, Parents and Grand Parents) and Humanitarian \& Compassionate (Refugees and Protected
Persons). All these categories lead to Permanent Resident (PR) status in Canada. Recently in 2019, there were 341,190 new immigrants admitted to Canada on immigration visa and the newcomers from India were in the majority (Statista, 2020). Some critics argue that after strict policies by Trump administration in US, the immigrants from India were typically looking for Canada. The migration rate from India to Canada went astonishing higher when the annual numbers surprisingly increased from 39,795 in 2016 to 85,585 in 2019. Indian immigrants made-up a quarter of total migrants to Canada in 2019 but earlier this percentage was only $14 \%$ in 2015 (Anderson, 2020: El-Assal, 2020).

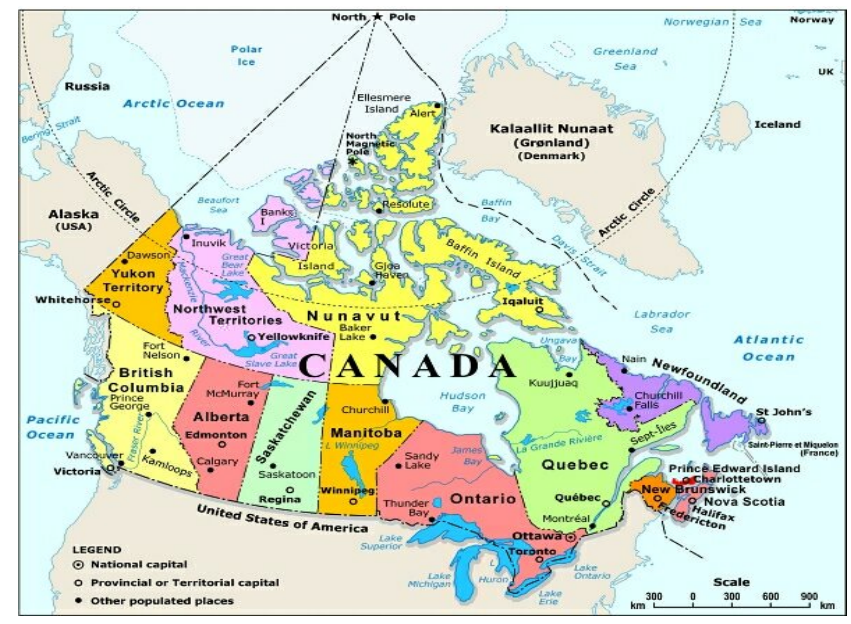

Source: Mother Earth Travel (2020)

\section{Problem Statement:}

India and Pakistan are the two neighboring countries in South Asian region. Pakistan was created from the northern part of India in 1947. People from both countries are excited to migrate to Canada but many groups and individuals belong to Pakistan raise their voice at community forums about the Canadian immigration policies by complaining that Indian applicants are given unfairly preference for immigration. The basic curiosity in descriptive-comparative research was to identify, compare and describe the issue after an in-depth analysis of the available data.

\section{Objectives:}

The objectives of the study are:

- To know the percentage of world population (men and women) who migrate to Canada every year? 
- To recognize the percentage of Indian migrants who get Canadian immigration each year?

- To describe the percentage of Pakistani immigrants who move to Canada yearly.

- To identify the level of percentage in the growth of Canadian population after immigration from India and Pakistan annually?

\section{LITRATURE REVIEW}

\section{Theoretical Framework:}

Although, there is no single theory which can clearly define the phenomenon of migration in a logical way presently, the study relied on Ravenstein's Law of Migration (1885) an eight points set of generalization concerning inter-country migration which guides to understand the trends of immigration and why do people move from one place to other whether locally or internationally. In this model, Ravenstein proclaims the economic reasons as the main cause of migration and females, comparably to males, are much eager or excited to migrate to the new place. The law of migration also asserts that mostly people migrate from rural areas than the natives of towns and this gap under the process of dispersion creates the flow of another migration. When people move to a rapidly growing town, new immigrants immediately come to fill the gap caused by the migration of other people. Ravenstein thinks that normally people move to a shortdistance place however migrants from long-distance areas move to the places which are the centers of commerce and industry (Cited in Lee, 1966). According to Ravenstein, there are various factors behind the decision of migration which include economic disorder, political situation, heated conflicts, civil war, culture and traditions, environmental conditions and advancement in technologies. Sometimes people decide to move for more than one reason. Migration could be voluntarily or involuntarily that is imposed or forced. Canadian history shows the both types of immigrants who left their country of previous residence by force or voluntarily and found refuge or asylum in Canada. There are very limited choices for the people who are forced to leave their country but the people who migrate voluntarily have numerous choices. The process of absorption when people move to a rapidly growing town and the gaps they leave are filled by the people who migrate form more distant areas. Each migration creates the space for another and the immigrants from long distance areas move to find work or business in the big centers of commerce and industries. People from rural areas are more eager to migrate than the residents of urban areas. Ravenstein declares economic reasons the main cause of migration and considers that females are more excited to migrate than males. After applying the law of migration in Canadian situation, the policies reflect that Canada's immigration system has following major categories of migration including Economic and Business Immigrants (Skilled workers, Canadian Experience, Investors, Entrepreneur and Self-Employed, Other Provincial Nominees and Pilot Programs), Family Class (Spouse, Dependent Child, Parents and Grand Parents) and
Humanitarians, Compassionate and Refugees grounds (Protected Persons, Refugees, Asylums). Bitesize (2020) endorsed the law of migration by Ravenstein and further explains that there could be various reasons behind the decision of migration. People leave their place of residence for economic, social, political and environmental reasons. The "push and pull factors" play a significant role in moving to particular areas when there are concerns of employment, wealth, safety, crimes, services, climate, stability, war, poverty, natural hazards, fertile lands, flooding, drought, crop failure. The economic immigration is the key focus which accelerates to other categories (Legal Line, 2020).

\section{Canadian Immigration History:}

The migration process to Canada was started from the time when very first group of settlers from England and France arrived to this land which is now known as a land of immigrants. The first Prime Minister of Canada Sir John Alexander McDonald was also an immigrant who was born in Scotland and moved to Canada in his childhood. In mass settlement during 1867 to 1914 , Canada opened its doors for people who were agriculturist with ruler lifestyle. Over one million immigrants crossed the pier 21 gateway, a national historic seaport site, to enter Canada between 1928 to 1971. Canada announced multiculturalism policy in 1971 to recognize the value of all citizens in the country regardless of their origin, ethnicity, language, race or religious believes (Live\&Learn,2016). According to census Canada 2011, the immigrants reported more than 200 different languages as their mother tongue in Canada however English and French are the two official languages spoken widely in country (Statistics Canada, 2018).

\section{Previous Studies:}

Over the past 200 years, millions of people have migrated to Canada from different European, Asian, Australia, African and American Countries. In early days, mostly people migrated to Canada from England, France, Germany, Ireland, Scotland, China, Italy, Ukraine, Netherland, Aboriginals, Scandinavia. In 1967, Canada eliminated its National Preference Policies which favored immigrants from European countries. The new changes allowed the authorities to give equal preference to the applications received from every country and it also made the procedure flexible for Asian and Latin immigrants to come to Canada (Edmonston, 2016). Since 1970, immigrants are also coming from South Asian Countries including India and Pakistan (CIC, 2012). Canadian Government is very supportive, it promotes the immigration cultural and sees the newcomers as a strong pillar of the country's economy. Canada is proud on its remarkable multiculturalism in the world (Immigration Direct, 2011). Newcomers are not burden on Canadian economy as they are educated in different fields, experienced with other languages skills and can help Canada to be competitive and succeeded in the global market (City of Windsor, 2017). Economic needs of Canada are majorly caused by an aging population in the nation and this is the reason for current increase of 
immigration invitations by Canadian authorities (Bascaramurty, 2017).

Canada offers permanent residency based on three grounds including economic development of the country through welleducated and highly skilled immigrants, allows reunification of the families who are already settled in Canada via sponsorship of selected family members like spouse, kids and parents, and to the protected persons under refugees or asylum seekers settlement (Chui and Maheux, 2007). Canada is, no doubt, hunting global talent and readily accepts the highly educated persons for immigration but observers suggest that Canadian labour market needs to do more to remain attractive in the world economy and invite more educated and experienced talent (King, 2009). Researchers discuss that immigrants' community living in smaller Census Metropolitan Areas (CMAs) in the province of Ontario is earning more or similar to the workforce born in Canada however Canadian-born workers living in large urban areas earn more than the immigrant workers. In some communities of Ontario, highly educated immigrants earn over $25 \%$ more than their Canadian-born colleagues but the number of these individuals are very few (King, 2009). Earlier, Bernard (2008) identified that Canada's demographic growth is dependent on its immigration program and migrants' community settled outside the major urban areas is earning same as the locals. Another study conducted by Akbari and Haider (2017) claimed that economic growth effects differently in smaller and larger provinces of Canada for both the immigrants and the people who were born in Canada. In smaller provinces, the positive effects of immigration on economic growth seem lower for both groups. According to literature review, Immigrants are earning good in small communities but Wiginton (2013) identified that welcoming initiatives in small areas are not enough to meet the needs, they are very limited due to shortage of resources and lack of institutional capacity. A research by Dolin and Young (2004) established that the per-capita immigration rate in Canada is largest in the world. 1n December 1997, Migration News published a report in its volume 4 by disclosing that majority of immigrants in the world are located in three countries including Canada. The other two countries are United States and Australia (cited in Grant, 1999). Another study on jobs for immigrants in new Canadian economy conducted by Hoe (2017) and the research is not completely satisfied on equality between immigrants and Canadian born workers in the employment sector but despite of all these issues, the Canadian immigration is still considered a golden opportunity for people. Meraj (2015) conducted a study in Health and Rehabilitation Sciences and finds that settlement in the new place is not easy for highly educated immigrants women who are forced to accept the jobs below their qualifications which ultimately impact badly on their health.

The immigration structure of Canada is based on economic factors and policy makers are changing the criteria accordingly (Bhuyan et al. 2017) and this is the reason that every year a large number of newcomers are belonged to economic class (Citizenship and Immigration Canada, 2012). A study by Collacot (2003) evaluated the Canadian immigration policy by arguing that only $10 \%$ of refugees' quota out of the total immigration flow is allocated to be settled in Canada and presently there is no favorable policy for those who want to migrate to Canada if their own economic situation is very limited. Collacot (2003) criticized by adding that policy makers should look for quality instead of quantity of new immigrants so the newcomers avail the opportunities to become successful in their new homeland. Kaushik and Drolet (2018) pointed out that despite of the Canadian policy in favor of economic, highly skilled and educated immigrants, the newcomers face hardship in Canada to search for jobs according to the qualifications, skills, professional experience and aptitude. Even the points-based system attracts to those who are able to join and contribute in Canadian economy and society by utilizing their skills and abilities.

The immigration system in Canada has been growing with many changes announced by the governments to meet the emerging needs. The old occupational targeting approach was to manage labour markets by filling the occupational shortage through immigration. Later, when the procedure was found ineffective and inefficient, the government overhauled the system and announced a new immigration law after making several changes. The new policy adopted stricter points-based selection criteria to have the positive impacts on Canadian economy (Variyam, 2007). Interestingly, after introducing a new point-based classification in Canada, some other countries like United Kingdom, Germany and Spain also considered to bring the similar techniques in their immigration systems (Oreopoulos, 2011).

Now, the question is why a large number of people still look for Canada when it is hard to find appropriate jobs in their own field, LIP-Renfrew and Lanark (2012) highlighted that sometimes the newcomers' present condition in Canada is still better than the situation they were facing back home. Normally, the newcomers avoid or hesitant to make complaints regardless of the difficulties they face after moving to Canada.

Mofina (2002) indicated that Toronto was the top destination for newcomers in North America when a large number of new immigrants 108,000 decided to reside in the city during 2000 batch. According to Association of Canadian Studies (cited in Mofina, 2002), the second top most destination of migrants was New York, then Los Angeles in U.S., and the Canadian city of Vancouver was on $5^{\text {th }}$ and Montreal ranked $8^{\text {th }}$. Canadian federal immigration programs also attract the provincial governments who have launched their own streams under Provincial Nominee Programs (PNP) and invite skilledequipped immigrants to be settled in their respective communities (Seidle, 2013). The previous studies on migration have evaluated the positive impact of migration on economies. 


\section{RESEARCH METHODOLOGY}

The research study is descriptive-comparative in nature which aimed to highlight the trend, frequency, percentage, characteristics or categories of immigration from India and Pakistan after analyzing the historical data without focusing on the policies, reasons and cause of preferences or priorities of the host country. Under the descriptive research design, the study only observed and measured the variables without manipulating or controlling them. It can be considered a case study of Canadian immigration to describe the percentage of migration from the above mentioned countries over the years according to their own population and the contribution they make in the growth of Canadian population.

The study is based on 20 years' quantifiable secondary data (2000 to 2019) collected from archives which was then refined and examined to analyze on the prescribed grounds for new findings. The data was collected from Statistics Canada and Open Data centers, Library and Archives Canada, Statista, and Immigration Canada. The analysis was done with the help of Microsoft Excel and other computer based software.

\section{IV.RESEARCH FINDINGS AND RESULTS}

This section of the study based on the data reports the results and findings of the research.

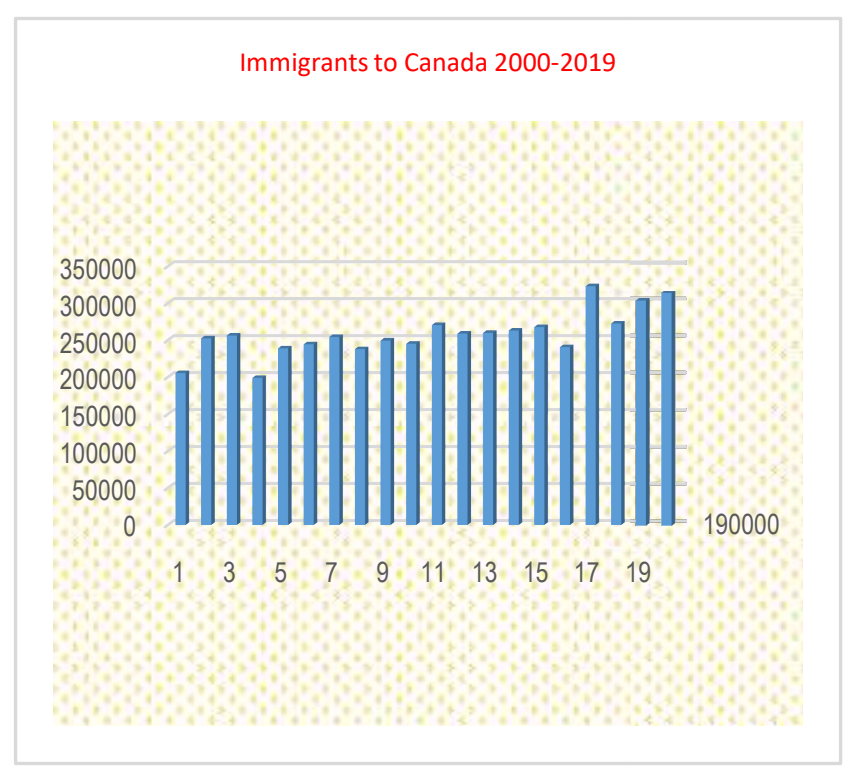

Source (Statista, 2020, prepared by the Author)

According to the previous twenty years of immigration data from 2000 to 2019 , averagely 252,962 migrants every year move to Canada on permanent residency visa. The lowest numbers of immigrants 199,177 were moved to Canada in 2003 and the maximum numbers of immigrants 323,190 were recorded during 2016.

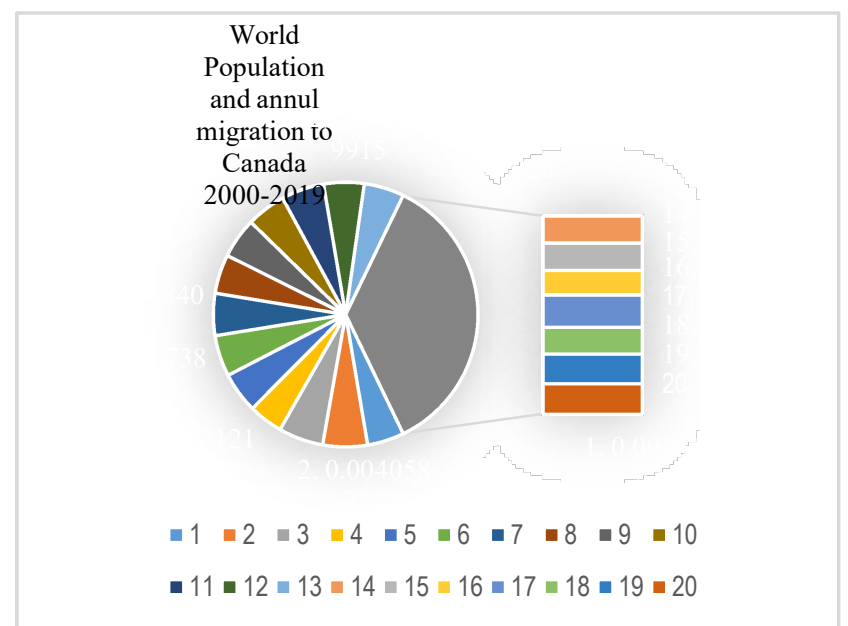

Source: (Prepared by the Author)

The analysis finds that averagely a very small portion of the world population $0.00385 \%$ move to Canada every year. The above Mean calculations show that during the previous 20 years, the largest numbers of migrants $0.004 \%$ were recorded in 2001 to 2014 except 2003 and then 2015 to 2019. The smallest number $0.003 \%$ for recorded for 2003 and 2015 . Since 2000 to 2019 , within the period of twenty years $5,159,230$ immigrants from worldwide have moved to Canada for permanent residence.

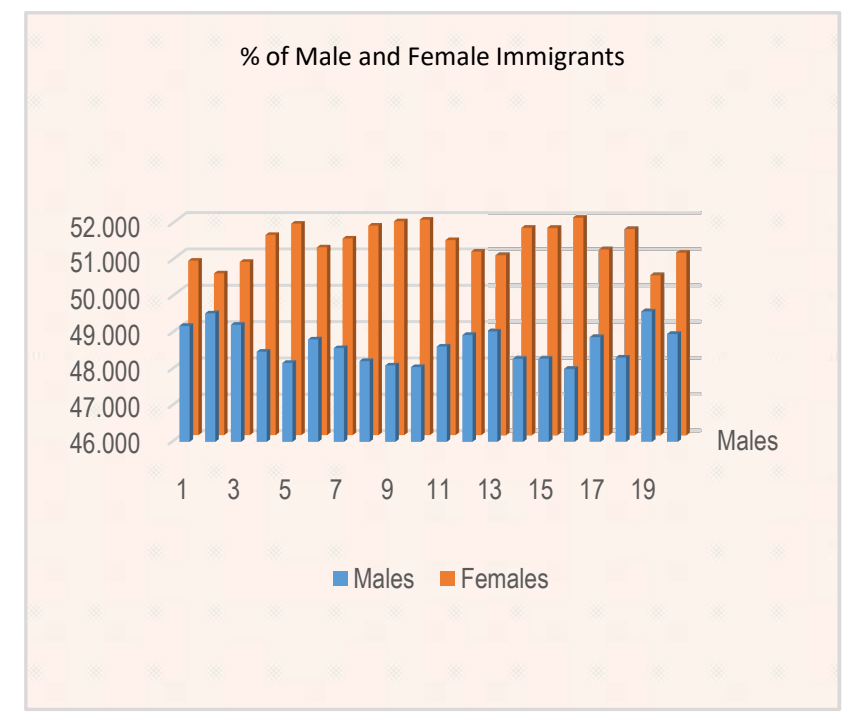

Source: (Prepared by the Author)

The research finds that averagely $48.66975 \%$ of Males from the world population move to Canada annually. The largest percentage of male population $49.593 \%$ moved to Canada in 2018. The smallest numbers of male migrants $48.008 \%$ moved to Canada in 2014. According to study calculations, a total of 2,511,784 male immigrants moved to Canada between 2000 to 2019 for permanent residence. The study finds that every year $51.33025 \%$ of female migrants get Canadian immigration and the largest portion of female immigrants $51.994 \%$ from the world population moved to Canada in 2015. The analysis shows that smallest amount of female 
immigrants $50.405 \%$ moved to Canada for permanent residence in 2018. The previous 20 years' data discloses that the number of female immigrants were higher than males between 2000 and 2019 and during this period 2,647,439 female immigrants moved to Canada for permanent living.

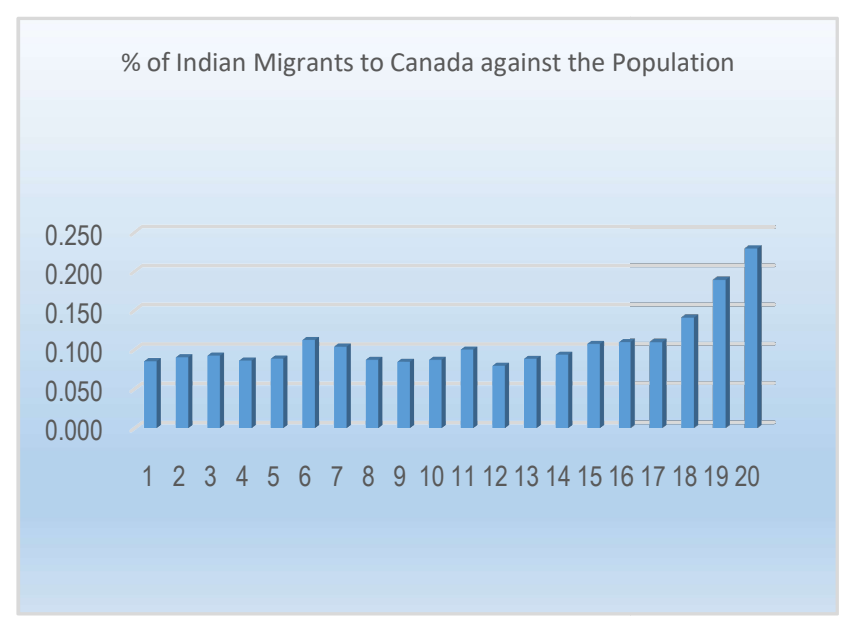

Source: (Prepared by the Author)

According to research findings, $0.00315 \%$ Indians get Canadian immigration and move to Canada annually. The largest portion of Indian population $0.006 \%$ moved to Canada in 2019 and the smallest population of $0.002 \%$ left the country for Canada in 2011. Since 2000, a total of 745,173 Indians moved to Canada for permanent residence.

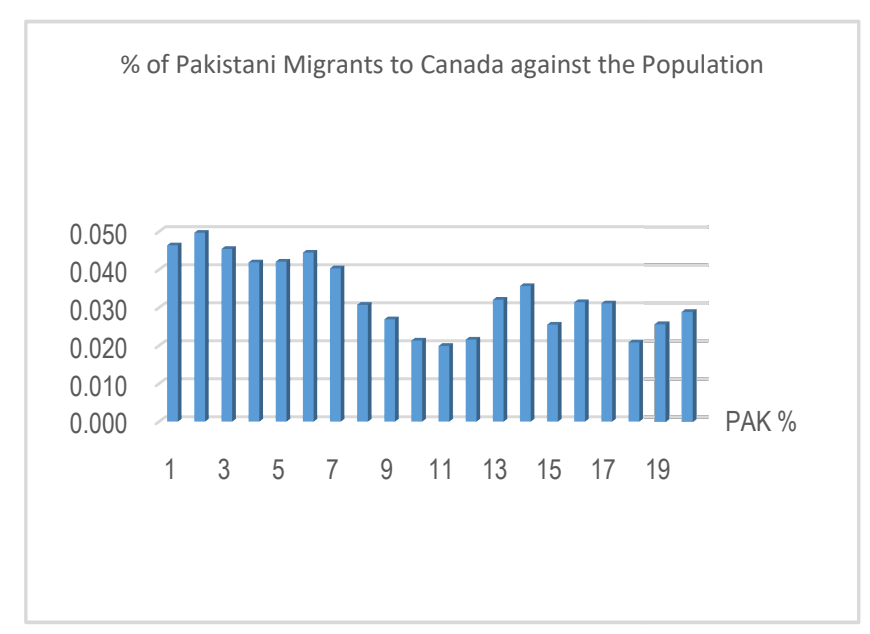

Source: (Prepared by the Author)

The research finds that every year $0.00665 \%$ of Pakistani population move to Canada and 2001 was the year when a largest portion of Pakistani population $0.011 \%$ moved to Canada for permanent residence. During 2009 to 2011 and in 2017 and 2018, the smallest quantity of $0.004 \%$ Pakistani population arrived to Canada on PR visa. The analysis reveals that within twenty years, 221,900 Pakistanis left the country to live in Canada permanently.

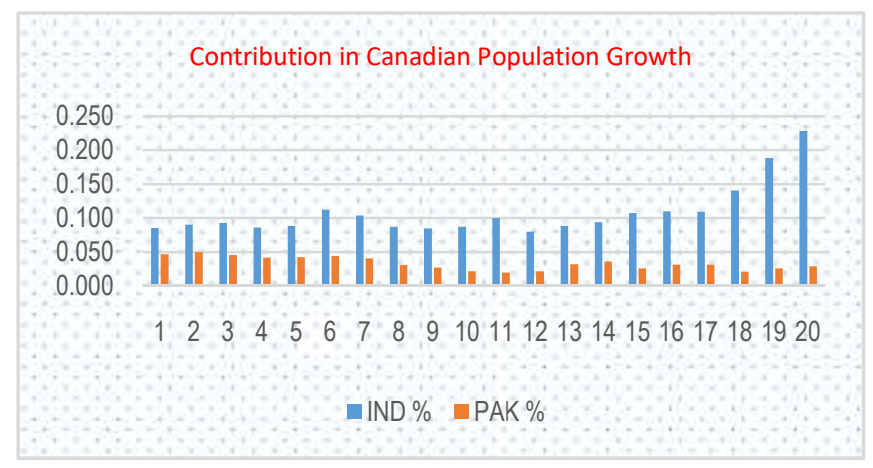

Source: (Prepared by the Author)

The study finds that averagely Canadian population is increasing $0.10825 \%$ annually due to the Immigrants from India. The largest increase in Canadian population $0.229 \%$ because of Indian immigrants was shown during the year of 2019 when 85,585 Indians moved to Canada for permanent residence. However, Canadian population was increased only $0.080 \%$ in 2011 when 27,485 Indians migrated to Canada.

The research finds that Canadian population is increased $0.03315 \%$ after the arrival of Pakistani immigrants. The highest increased 0.050 was shown during 2001 when 15,354 Pakistani immigrants moved to Canada for permanent living. The smallest portion of increase in Canadian population $0.020 \%$ was recorded in 2010 when only 6,810 Pakistanis got the immigration visa.

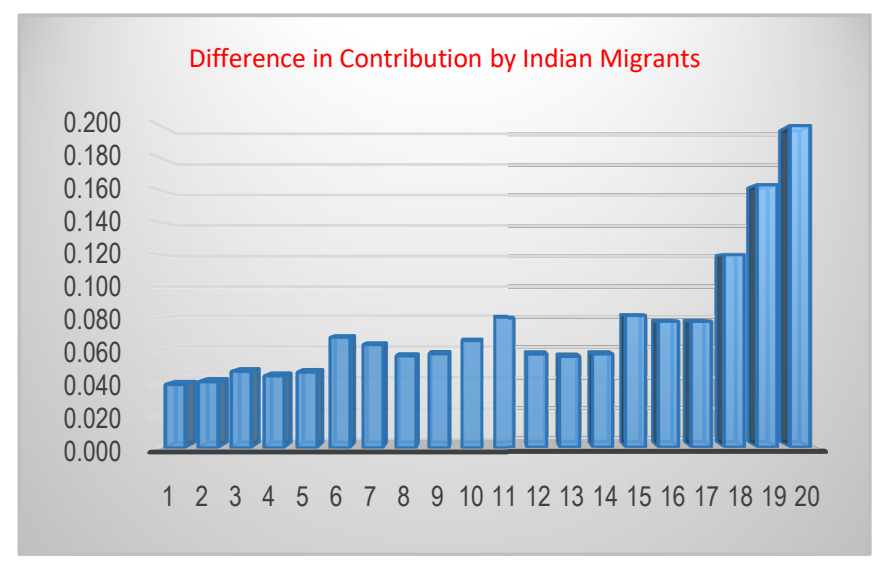

Source: (Prepared by the Author)

The study finds that Indian immigrants increase the Canadian population $0.076 \%$ more as compared to the immigrants from Pakistan every year. The largest difference of $0.20 \%$ was recorded in 2019 and the smallest $0.04 \%$ in 2001 due to the immigrants from India as compared to Pakistan. The 13.791\% of existing population of Canada were made due to the immigration form worldwide during twenty years' period from 2000 to 2019.

\section{DUSCUSSION OF FINDINGS}

The immigration system of Canada is quite old and it started from the arrival of English and French settlers to this soil. A Scottish born immigrant Sir John McDonald became the first 
prime Minister of Canada in 1867. Canada is known as "the land of immigrants" because of the large-scaled migration. The research was designed to analyze various facts related to the increasing quantity of migrants to Canada. The study collected the previous twenty year's immigration data from 2000 to 2019 and analyzed it to describe the percentage of world population (males and females) who migrate to Canada each year, to recognize the percentage of Indians who get Canadian immigration annually, to know the percentage of Pakistanis who move to Canada every year and finally to identify the level of percentage in which the Canadian population is growing yearly after migration from India and Pakistan?

According to the findings based on twenty years' data, $0.00385 \%$ of the total population in the world moves to Canada every year. Canada offers their permanent residence visa to approximately 257,962 new immigrants each year from around the globe since 2000. Until 2019, around $5,159,230$ newcomers have moved to Canada for permanent residence after securing immigration visas. The majority of immigrants were the females with $51.33 \%$ and the male immigrants were only $48.67 \%$. During the period covered in research analysis, 2,647,439 females and 2,511,784 males moved to Canada after getting immigration.

The rounded percentage of migration from India to Canada is $0.003 \%$ based on the total Indian population and within twenty years 745,173 Indians moved to Canada as immigrants in various categories. The rounded percentage of migrants from Pakistan to Canada is $0.006 \%$ against the total population of Pakistan. Within the twenty years, 221,900 Pakistanis left the country for Canada. Although, the numbers of Pakistani immigrants to Canada seem lower than Indians however Pakistanis get more permanent visas than Indians as per the total population of the said countries.

It is clear that Canada wants to increase its population through immigration and the newcomers from India contributes $0.108 \%$ every year in Canadian population since 2000 . The portion of Pakistani immigrants in the overall growing Canadian population is $0.033 \%$ annually. The figures show that total annual increase in Canadian population due to the immigrants from worldwide is $0.759 \%$ averagely. When we compare the contribution of Indian and Pakistani immigrants in the growth of Canadian population, the analysis represents the $0.076 \%$ difference between Indians and Pakistani immigrants toward the increase of total population in Canada yearly. India definitely makes huge contribution in Canadian population than Pakistan.

It is also appropriate to mention that $13.791 \%$ of increase in existing Canadian population within the period of twenty years was happened due to the worldwide migration to Canada from 2000 to 2019 and the trend seems to be continued in coming years.

\section{VI.CONCLUSION}

The descriptive-comparative study examined and compared the percentage of migrants against the world population who migrate to Canada for permanent residence. The study also compared the percentage of males and female migrants under gender analysis according to the total numbers of immigrants who arrive to Canada every year. As the main motive of this research was to analyze the numbers of migration from India and Pakistan against the total residents of their countries and its contribution in the growth of Canadian population. The Law of Migration by Ravenstein (1885) helped to understand the immigration phenomena and worldwide migration trends to Canada. The study analyzed that Pakistani migrants are larger than the migrants from India. The total population in India is many times bigger than Pakistan and the quantity of Indian applicants must also be higher. The analysis highlights that the overall percentage of Pakistani migrants based on their current population is still higher than India however there is no data available to confirm of how many applications for immigration are received from both countries and what is the rate of rejection or approval by Citizenship and Immigration Canada (CIC). The existing study provides the answers of the research problem from the twenty years' available data however another research is strongly recommended to clearly analyze the total applicants from India and Pakistan, the percentage of success and rejection, and as well as the application processing timeline in which an application is decided from the beginning of submission.

\section{REFERNCES}

[1] Akbari, A. H. and Haider, A. (2017) Impact of Immigrants on Economic Growth in Canada and its Smaller Provinces, November 2017, Journal of International Migration and Integration 19 (1) $: 1-14$

[2] Anderson, S. (2020) Indians Immigrating to Canada at an Astonishing Rate, Forbes.com, Retrieved 04 March 2020 from https://www.forbes.com/sites/stuartanderson/2020/02/03/indiansimmigrating-to-canada-at-an-astonishing-rate/

[3] Bascaramurty, D. (2017) Canada aims for immigration boost to buttress economy as population ages, The Globe and Mail, Retrieved 13 October 2020 from Canada aims for immigration boost to buttress economy as population ages - The Globe and Mail, Edition November 01, 2017

[4] Bernard, A. 2008. Immigrants in the Hinterlands. Perspectives, January 2008, Statistics Canada - Catalogue no. 75-001-X, 7: 5-14.

[5] Bhuyan, R., Jeyapal, D., Ku, J., Sakamoto, I. and Chou, E. (2017), "Branding 'Canadian experience' in immigration policy: nation building in a neoliberal era", Int. Migration \& Integration, Vol. 18 No. 1, pp. 47-62

[6] Bitesize (2020) Migration Trends: Why do people migrate, www.bbc.co.uk, Retrieved 10 November 2020 from Why do people migrate? - Migration trends - GCSE Geography Revision BBC Bitesize

[7] Britannica (2020) Canada, Retrieved 12 November 2020 from Canada - Native peoples | Britannica

[8] Chui, T, K. Tran and H. Maheux. 2007. Immigration in Canada: A Portrait of the Immigrant Population, 2006 Census. Ottawa: Statistics Canada - Social and Aboriginal Statistics Division. http://www12.statcan.ca/english/census06/analysis/immcit/pdf/97557- XIE2006001.pdf

[9] CIC (2012) Discover Canada: the right of responsibilities of citizenship, Ottawa, Canada: Ministry of Citizenship and Immigration 
[10] City of Windsor (2017) Busting the Myths About Immigration in Canada, South Essex Community Council SECC, Retrieved 11 October 2020 from myths about immigration.pdf (citywindsor.ca)

[11] Collacot, M, (2003) Canada's Immigration Policy: The Need for Major Reform, $2^{\text {nd }}$ ed. Public Policy Sources Number 64, Vancouver, BC. Canada: The Fraser Institute Occasional Paper, Pp. 6-43

[12] Dolin, B. and Young, M. (2004) "Canada's Immigration Program." Parliamentary Information and Research Service Background Paper BP-190E.

[13] Edmonston, B. (2016) Canada's immigration trends and patterns, Canadian Studies in Population 43, no. 1-2 (2016): 78-116.

[14] El-Assal, K (2020) A quarter of Canada's immigrants arrived from India in 2019, CIC News, Retrieved 05 March 2020 from A quarter of Canada's immigrants arrived from India in 2019 | Canada Immigration News (cicnews.com)

[15] Grant, M. L. (1999) IMMIGRATION IN CANADA: CONTEXT, ASSIMILATION AND LABOUR MARKET IMPACTS, Doctoral Thesis, Graduate Department of Economics University of Toronto, Canada

[16] Hoe, A. (2017) Working in 'Bad Jobs': Immigrants in the New Canadian Economy, Doctoral Thesis, Department of Sociology University of Toronto, Canada

[17] Immigration Direct (2011) Canada Immigration Statistics Facts, immigrationdirect.ca, Retrieved 21 November 2020 from Canada Immigration Statistics Facts - Immigration Direct Canada

[18] Kaushik, V, and Drolet, J. (2018) Review: Settlement and Integration Needs of Skilled Immigrants in Canada, MDPI Social Sciences, 03 May 2018, Basel, Switzerland,

[19] King, K. M. (2009) The Geography of Immigration in Canada: Settlement, Education, Labour Activity and Occupation Profiles, Martin Prosperity Institute, Rotman School of Management, University of Toronto

[20] Lee, E. S. (1966) A Theory of Migration. Demography, Retrieved 15 November 2020 from https://doi.org/10.2307/2060063, 3, 4757

[21] Legal Line (2020) Who can immigrate to Canada? legaline.ca, Retrieved 12 November 2020 from Who can immigrate to Canada? - FREE Legal Information | Legal Line

[22] Live \& Learn (2016) Canada's immigration history, livelearn.ca, Retrieved 15 October 2020 from Canada's immigration history Live \& Learn, posted February 22, 2016
[23] Local Immigration Partnership [LIP] Renfrew and Lanark. (2012). The Rural Mosaic: Building on Strengths \& Seizing Opportunities. Pembrooke, Ontario

[24] Meraj, N. (2015) Settlement Experiences of Professional Immigrant Women in Canada, USA, UK and Australia, Master Thesis, The University of Western Ontario, Canada

[25] Mofina Rick (2002). "Canada Becoming a Nation of Asians." Ottawa Citizen. 03 July 2002. Toronto, Canada: Post Media Network Inc.

[26] Mother Earth Travel (2020) Map of Canada, Retrieved 12 October 2020 from Map of Canada (motherearthtravel.com)

[27] Munroe, S. (2019) What Was Canadian Confederation? Understand the Formation of Canada, ThoughtCo. Retrieved 16 October 2019 from What Was Canadian Confederation? (thoughtco.com)

[28] Oreopoulos, P. (2011) Why Do Skilled Immigrants Struggle in the Labor Market? A Field Experiment with Thirteen Thousand Resumes, American Economic Journal: Economic Policy 3 (November 2011): 148-171 http://www.aeaweb.org/articles.php?doi=10.1257/pol.3.4.148

[29] Ravenstein, E. G (1885) "The Law of Migration" Journal of the Royal Statistical Society, XLVIII, Part 2 (June 1885) 167-227, also Reprint No. S-482 Bobbs-Merrill Series in the Social Science

[30] Seidle, F. L. (2013) Canada's Provincial Nominee Immigration Programs Securing Greater Policy Alignment, Montreal, Canada: IRPP Studies Number 43, December 2013

[31] Statista (2020) Number of Permanent Residents admitted to Canada in 2019, by status, statista.com, Retrieved 25 November 2020 from - Number of permanent residents admitted to Canada, by status $2019 /$ Statista

[32] Statistics Canada (2018) Linguistic Characteristic of Canadians, statcan.gc.ca, Retrieved 31 October 2020 from Linguistic Characteristics of Canadians (statcan.gc.ca)

[33] Variyam, M. N. (2007) Canada 's Skilled Worker Immigration Regulation and Its Impact on the Canadian Economy, Laws and Business Reviews of Americas, Volume 3, November 2, Article 11

[34] Wiginton, L. K. (2013) Canada's Decentralised Immigration Policy through a local Lens: How Small Communities Are Attracting and Welcoming Immigrants, Montreal, Canada: School of Urban Planning McGill University 


\section{APPENDIX A:}

Note 1: Annual Growth in total Canadian Population by the Immigrants, 2000-2019

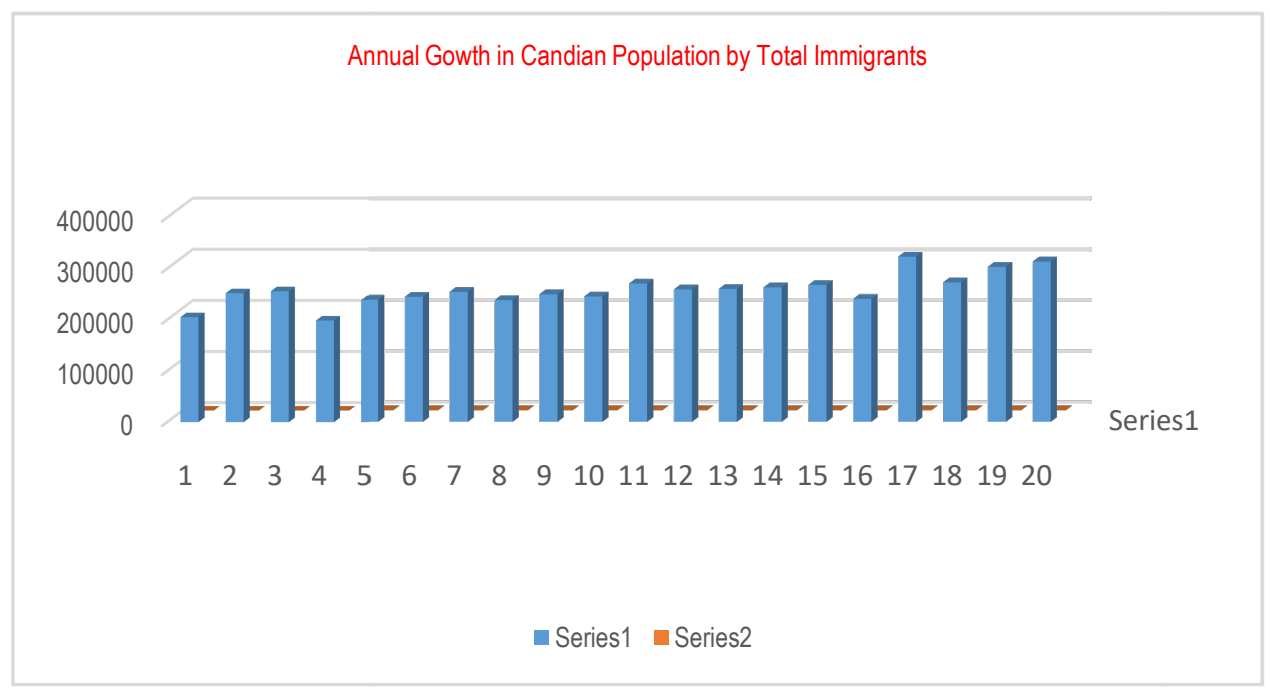

Note 2: Growth in Canadian Population by Male Immigrants, 2000-2019

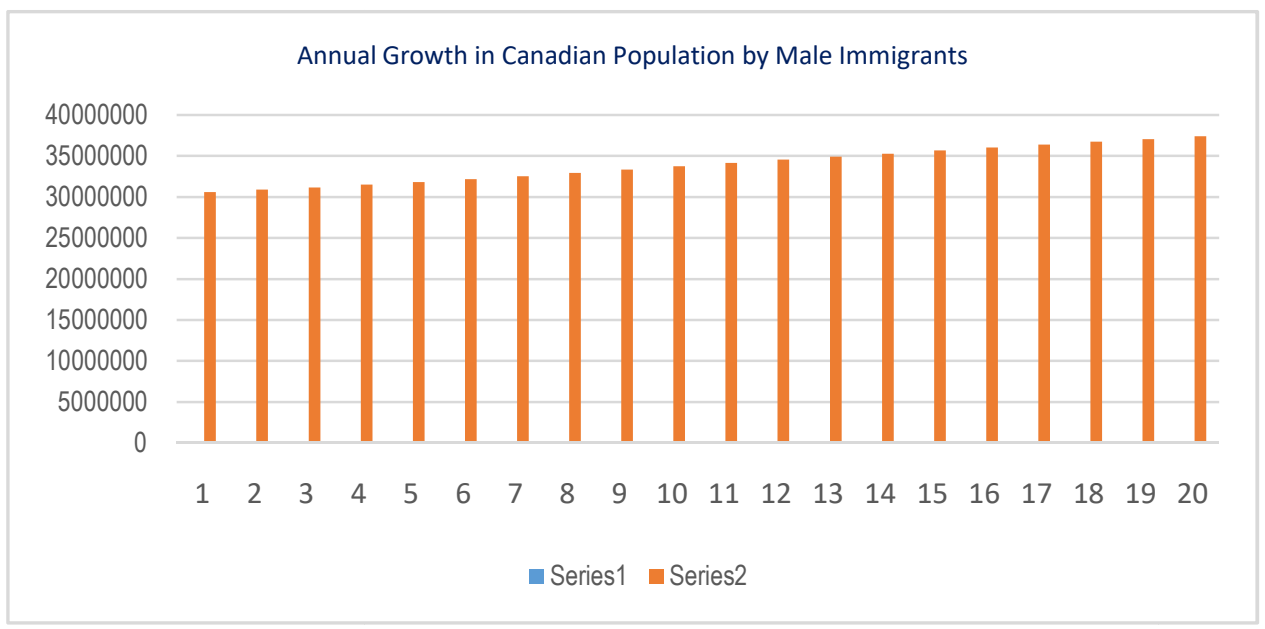

Note 3: Growth in Canadian Population by Female Immigrants, 2000-2019

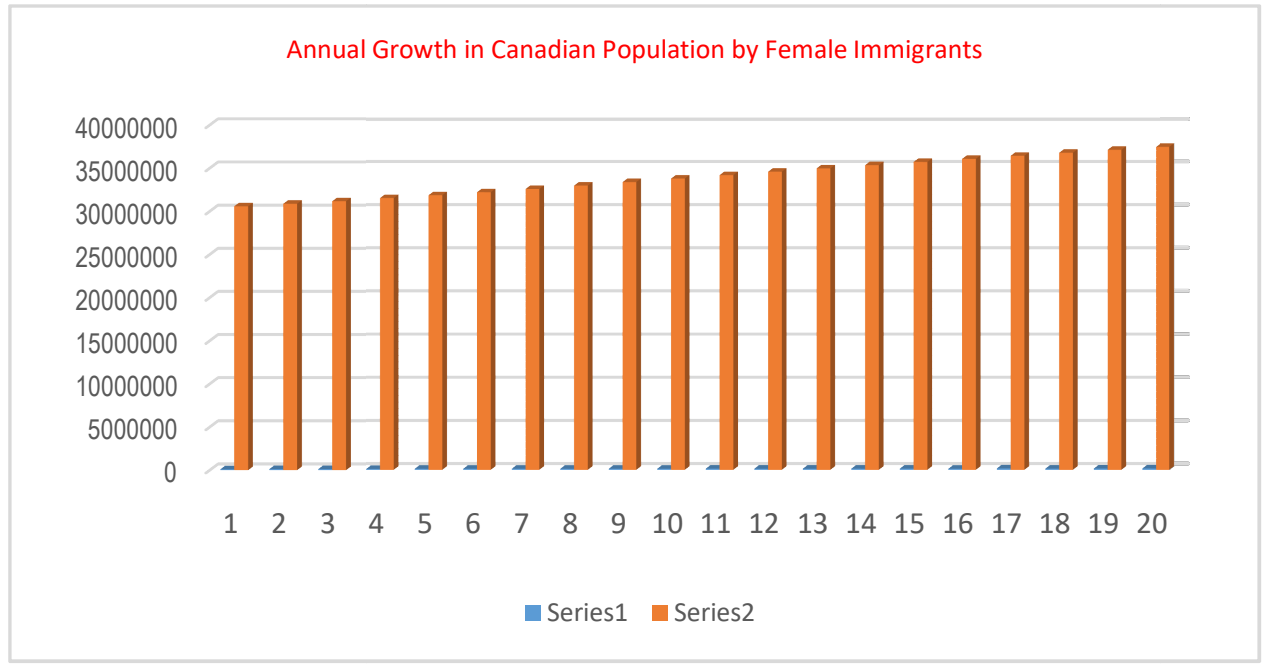


Appendix B:

Note 1: Canadian Immigration Data by Genders 2000-2019

\begin{tabular}{|c|c|c|c|c|c|c|c|}
\hline Year & World Population & $\begin{array}{c}\text { Immigrants to } \\
\text { Canada }\end{array}$ & $\begin{array}{c}\text { \% of W. } \\
\text { to Can }\end{array}$ & $\begin{array}{c}\text { Total } \\
\text { Males }\end{array}$ & $\begin{array}{c}\text { \% of } \\
\text { Males }\end{array}$ & $\begin{array}{c}\text { Total } \\
\text { Females }\end{array}$ & $\begin{array}{c}\text { \% of } \\
\text { Females }\end{array}$ \\
\hline 2000 & $6,143,493,823$ & 205710 & 0.003 & 101195 & 49.193 & 104515 & 50.807 \\
\hline 2001 & $6,222,626,606$ & 252530 & 0.004 & 125108 & 49.542 & 127419 & 50.457 \\
\hline 2002 & $6,301,773,188$ & 256410 & 0.004 & 126218 & 49.225 & 130187 & 50.773 \\
\hline 2003 & $6,381,185,114$ & 199170 & 0.003 & 96566 & 48.484 & 102604 & 51.516 \\
\hline 2004 & $6,461,159,389$ & 239080 & 0.004 & 115179 & 48.176 & 123904 & 51.825 \\
\hline 2005 & $6,541,907,027$ & 244580 & 0.004 & 119415 & 48.825 & 125163 & 51.175 \\
\hline 2006 & $6,623,517,833$ & 254370 & 0.004 & 123587 & 48.586 & 130787 & 51.416 \\
\hline 2007 & $6,705,946,610$ & 238130 & 0.004 & 114842 & 48.227 & 123283 & 51.771 \\
\hline 2008 & $6,789,088,686$ & 249620 & 0.004 & 120085 & 48.107 & 129537 & 51.894 \\
\hline 2009 & $6,872,767,093$ & 245290 & 0.004 & 117893 & 48.063 & 127396 & 51.937 \\
\hline 2010 & $6,956,823,603$ & 270580 & 0.004 & 131573 & 48.626 & 139008 & 51.374 \\
\hline 2011 & $7,041,194,301$ & 259110 & 0.004 & 126822 & 48.945 & 132288 & 51.055 \\
\hline 2012 & $7,125,828,059$ & 260040 & 0.004 & 127521 & 49.039 & 132515 & 50.959 \\
\hline 2013 & $7,210,581,976$ & 263100 & 0.004 & 127045 & 48.288 & 136056 & 51.713 \\
\hline 2014 & $7,295,290,765$ & 267920 & 0.004 & 129385 & 48.292 & 138539 & 51.709 \\
\hline 2015 & $7,379,797,139$ & 240760 & 0.003 & 115583 & 48.008 & 125180 & 51.994 \\
\hline 2016 & $7,464,022,049$ & 323190 & 0.004 & 157991 & 48.885 & 165201 & 51.116 \\
\hline 2017 & $7,547,858,925$ & 272710 & 0.004 & 131773 & 48.320 & 140934 & 51.679 \\
\hline 2018 & $7,631,091,040$ & 303330 & 0.004 & 150431 & 49.593 & 152894 & 50.405 \\
\hline 2019 & $7,713,468,100$ & 313600 & 0.004 & 153572 & 48.971 & 160029 & 51.030 \\
\hline
\end{tabular}

Note 3: Total Migration and its contribution in Canadian Population

\begin{tabular}{|c|c|c|c|}
\hline Year & Total Immigrants & Canada Population & \% of Migration \\
\hline 2000 & 205710 & $30,588,383$ & 0.672510214 \\
\hline 2001 & 252530 & $30,880,073$ & 0.817776564 \\
\hline 2002 & 256410 & $31,178,263$ & 0.822399888 \\
\hline 2003 & 199170 & $31,488,048$ & 0.632525713 \\
\hline 2004 & 239080 & $31,815,494$ & 0.751457765 \\
\hline 2005 & 244580 & $32,164,309$ & 0.760408066 \\
\hline 2006 & 254370 & $32,536,987$ & 0.781787201 \\
\hline 2007 & 238130 & $32,930,794$ & 0.723122558 \\
\hline 2008 & 249620 & $33,337,638$ & 0.748763305 \\
\hline 2009 & 245290 & $33,746,093$ & 0.72686933 \\
\hline 2010 & 270580 & $34,147,564$ & 0.792384488 \\
\hline 2011 & 259110 & $34,539,159$ & 0.750191978 \\
\hline 2012 & 260040 & $34,922,030$ & 0.744630252 \\
\hline 2013 & 263100 & $35,296,528$ & 0.745399094 \\
\hline 2014 & 267920 & $35,664,337$ & 0.751226639 \\
\hline 2015 & 240760 & $36,026,676$ & 0.66828258 \\
\hline 2016 & 323190 & $36,382,944$ & 0.888300848 \\
\hline 2017 & 272710 & $36,732,095$ & 0.742429747 \\
\hline 2018 & 303330 & $37,074,562$ & 0.818162059 \\
\hline 2019 & 313600 & $37,411,047$ & 0.838255075 \\
\hline
\end{tabular}

